\title{
OPPORTUNITIES AND CHALLENGES IN SUSTAINABILITY OF VERTICAL FARMING: A REVIEW
}

\author{
FATEMEH KALANTARI*, OSMAN MOHD TAHIR, RAHELEH AKBARI JONI \\ AND EZAZ FATEMI
}

Faculty of Design and Architecture, University Putra Malaysia, Kuala Lumpur, Malaysia, *Corresponded author - e-mail: Fatimah.Kalantari@gmail.com

Received: $4^{\text {th }}$ April 2017, Accepted: $20^{\text {th }}$ June 2017

\begin{abstract}
As the world population continues to grow at a rapid rate, accompanied by a substantial growth in food demand which is expected to transpire in the next 50 years, $80 \%$ of the population will be living in urban areas. In order to feed this growing population, there is a need for sustainable urban food. Producing sustainable urban food requires considering all factors of sustainability collectively including, environmental, social and economic advancement. A new method that has been proposed to address the issue of sustainability and to meet the growing food demand is, designing and implementing vertical farms. Vertical farming is a concept that involves cultivating plants with livestock on vertically inclined surfaces such as in skyscrapers in urban areas, where there is a lack of available land and space. However, there is a paucity of information and a limited number of published critical reviews on Vertical farming in urban areas. This study, in an attempt to review the major opportunities and challenges of Vertical Farming, uses the framework of sustainability to examine the role of it in prospective food provision in cities. This study is a critical review of 60 documents from related published papers from relevant journals and scientific online databases. Vertical Farming can be potentially beneficial in increasing food production, maintaining high quality and safety and contributing to sustainable urban farming. Well-known advantages of growing food within the urban territory can be beneficial environmentally, socially and economically. Vertical farms can also provide solutions for increasing food security worldwide.
\end{abstract}

Keyword: Vertical Farming (VF), Food Security, Urban Agriculture, Sustainable Urban Food

\section{INTRODUCTION}

Fundamental changes are predicted to occur in the upcoming 50 years accompanied by higher demand for food, all across the world as the world population continues to grow exponentially (Banerjee \& Adenaeuer, 2014). The world population is predicted to reach an estimated 9 billion by 2050 (Despommier et al., 2013), and cities will be hosting about $80 \%$ of this population (Despommier, 2010; Islam \& Siwar, 2012). Currently, there is approximately 800 million hectares of land that is designated to soil-based farming globally, which constitutes about $38 \%$ of the total global land area. Moreover, $80 \%$ of the total arable 
land is currently being utilized across the globe (Ellingsen \& Despommier, 2008). Due to the growing food demand, there is a need for utilizing more arable land for farming as swell as intensifying farming efforts that would affect global agriculture. A new method that could potentially meet this demand, is in designing and devloping vertical farms (Despommier, 2013). The proposed designs can be tested through new technologies (Despommier, 2011; Glaser, 2012), however, VF is a fairly new concept and little studies have explored the issue of integrating it in the urban context.

In theory, Vertical Farming (VF) is an agricultural technique involving large-scale food production in high-rise buildings that enables fast growth and planned production by controlling environmental conditions and nutrient solutions to crops based on hydroponics (Figure 1), using cutting-edge greenhouse methods and technologies (Abel, 2010; Banerjee \& Adenaeuer, 2014; Despommier, 2010, 2011). According to Perez's research (2014), VF incorporates both discplines of engineering and natural sciences, and has multiple applications in both society and the environment (Perez, 2014).

Recently, producing sustainable food in cities has garnered much interest and attention in many academic and practical fields (Despommier, 2013; Specht et al., 2014). While there are still limited daunting technical and practical applications problems in regarding implementing the VF. However at present, these farms are largely growing and produce different types of crops inside cities such as China, Holland, South Korea, Japan, Canada, Italy, U.S, Singapore, United Arab Emirates, and England (Sivamani, Bae, \& Cho, 2013). Table.1 present the details of most effective vertical farms in around the world in different countries by evaluation of feasibility of VF for various climate/geographical areas by their type and technologies. According to Table 1, implementation and knowledge related to VF are growing in number, capacity and size. However, spatial distribution of VF shows that the evaluation of feasibility of VF for various climate or geographical areas as well as regional characteristics are largely growing. Because the plants will be grown indoors by controlled environment agricultural techniques, then changing of seasons will have no effect on the crops. It is obvious the various amount and types of products determined the VF is not just happening, it is prospering at multiple cities with different regional characteristics around the world. 
Table 1: Details of some effective Vertical Farming around the world

\begin{tabular}{|c|c|c|c|c|c|c|c|c|c|}
\hline $\mathbf{N}$ & Name & Location & Height & $\begin{array}{l}\text { Type of } \\
\text { Building }\end{array}$ & Products & Area & Technology & year & Website \\
\hline 1 & $\begin{array}{l}\text { The Plant } \\
\text { Vertical } \\
\text { Farm }\end{array}$ & Chicago, IL & 3story & $\begin{array}{l}\text { Existing } \\
\text { building } \\
\text { in } 19 \\
\text { century }\end{array}$ & $\begin{array}{l}\text { Wide variety of } \\
\text { edible crops } \\
\text { includes an } \\
\text { artisanal brewery, } \\
\text { kombucha } \\
\text { brewery, } \\
\text { mushroom farm, } \\
\text { and bakery, } \\
\text { Tilapia }\end{array}$ & $\begin{array}{l}100,000 \\
\text { sq.ft }\end{array}$ & $\begin{array}{l}\text {-Aquaponics systems and } \\
\text { fish breeding areas } \\
\text { - Hydroponic } \\
\text {-Recycling waste to energy } \\
\text { - Using biogas from an } \\
\text { anaerobic digester } \\
\text {-Natural sun energy }\end{array}$ & 2013 & $\begin{array}{l}\text { www.plantchica } \\
\text { go.com }\end{array}$ \\
\hline & $\begin{array}{l}\text { S } \\
\text { ky Greens } \\
\text { Farms }\end{array}$ & Singapore & $9 \mathrm{~m}$ & New & $\begin{array}{l}\text { leafy green } \\
\text { vegetables }\end{array}$ & $600 \mathrm{~m}$ & $\begin{array}{l}\text {-Aeroponuic system } \\
\text {-Low carbon hydraulic } \\
\text { water-driven } \\
\text {-Natural sun energy }\end{array}$ & 2009 & $\begin{array}{l}\text { www.skygreens } \\
\text {.appsfly.com }\end{array}$ \\
\hline & $\begin{array}{ll} & V \\
\text { ertiCrop } \\
\text { TM }\end{array}$ & $\begin{array}{l}\text { Vancouver, } \\
\text { Canada }\end{array}$ & & $\begin{array}{l}\text { Rooftop } \\
\text { of } \\
\text { existing } \\
\text { building }\end{array}$ & $\begin{array}{l}\text { Leafy greens, } \\
\text { micro greens, and } \\
\text { strawberries }\end{array}$ & $\begin{array}{l}50 * 75 \\
\text { Sq.ft, } 120 \\
\text { racks with } 24 \\
\text { growing trays } \\
\text { on each rack = } \\
16 \text {-acre farm. }\end{array}$ & $\begin{array}{l}\text {-Fully automated system } \\
\text { - Closed loop conveyor } \\
\text { hydroponic } \\
\text {-Room temperature, } \\
\text { lighting, fertilization, } \\
\text { irrigation and recapturing } \\
\text { of the water being used } \\
\text { - Natural and artificial light }\end{array}$ & 2009 & $\begin{array}{l}\text { www.verticrop. } \\
\text { com }\end{array}$ \\
\hline 4 & $\begin{array}{l}\text { Republic of } \\
\text { South } \\
\text { Korea VF }\end{array}$ & $\begin{array}{l}\text { South } \\
\text { Korea }\end{array}$ & 3 story & New & $\begin{array}{l}\text { leafy green } \\
\text { vegetables, almost } \\
\text { wheat, and corn }\end{array}$ & $450 \mathrm{~m}^{2}$ & $\begin{array}{l}\text {-Renewable resources like } \\
\text { geothermal and solar } \\
\text {-Automated rack system } \\
\text { - LED }\end{array}$ & 2011 & $\begin{array}{l}\text { www.cityfarmer } \\
\text {.info/ }\end{array}$ \\
\hline 5 & $\begin{array}{l}\text { Nuvege } \\
\text { plant } \\
\text { factory }\end{array}$ & $\begin{array}{l}\text { Japan } \\
\text { (Kyoto) }\end{array}$ & 4 story & & $\begin{array}{l}\text { Leafy green } \\
\text { vegetables }\end{array}$ & $\begin{array}{l}30,000 \\
\text { horizontal } \\
\text { sq.ft } \\
57,000 \text { sq.ft of } \\
\text { vertical } \\
\text { growing } \\
\text { space }\end{array}$ & $\begin{array}{l}\text {-Automated rack system } \\
\text {-LED grow lights } \\
\text {-Hydroponics }\end{array}$ & & $\begin{array}{l}\text { www.nuvege.co } \\
\mathrm{m}\end{array}$ \\
\hline
\end{tabular}


Journal of Landscape Ecology (2018), Vol: 11 / No. 1.

\begin{tabular}{|c|c|c|c|c|c|c|c|c|c|}
\hline 6 & Plantlab VF & $\begin{array}{l}\text { Den Bosch, } \\
\text { Holland }\end{array}$ & $\begin{array}{l}3 \text { story } \\
\text { under- } \\
\text { ground }\end{array}$ & $\begin{array}{l}\text { Existing } \\
\text { building }\end{array}$ & $\begin{array}{l}\text { every imaginable } \\
\text { crop, including } \\
\text { beans, corn, } \\
\text { cucumbers, } \\
\text { tomatoes, and } \\
\text { strawberries }\end{array}$ & & $\begin{array}{l}\text {-Without the use of } \\
\text { daylight } \\
\text { - Advanced LED } \\
\text {-Aeroponic and hydroponic }\end{array}$ & 2011 & $\begin{array}{l}\text { www.plantlab.n } \\
1 /\end{array}$ \\
\hline 7 & $\begin{array}{l}\text { Vertical } \\
\text { Harvest } \\
\text { plans2 }\end{array}$ & $\begin{array}{l}\text { Jackson } \\
\text { Wyoming, } \\
\text { USA }\end{array}$ & 3 story & New & $\begin{array}{l}\text { tomatoes, } \\
\text { strawberries, } \\
\text { lettuce, and micro } \\
\text { greens }\end{array}$ & $\begin{array}{l}500 \text { sq.ft. } \\
\text { footprint into } \\
18,000 \text { sq.ft., } \\
\text { or four times } \\
\text { the growing } \\
\text { area }\end{array}$ & $\begin{array}{l}\text {-Recirculating hydroponic } \\
\text { methods } \\
\text { - LED }\end{array}$ & 2012 & $\begin{array}{l}\text { www.verticalha } \\
\text { rvestjackson.co } \\
\text { m/ }\end{array}$ \\
\hline 8 & $\begin{array}{l}\text { Planned } \\
\text { Vertical } \\
\text { Farm }\end{array}$ & $\begin{array}{l}\text { Linkoping, } \\
\text { Sweden }\end{array}$ & $\begin{array}{l}17 \\
\text { story }\end{array}$ & New & $\begin{array}{l}\text { Asian leafy green } \\
\text { vegetables }\end{array}$ & & \begin{tabular}{l}
\multicolumn{1}{c}{-Aeroponic } \\
-Hydroponic \\
-Using waste products in \\
the process \\
- Natural lighting
\end{tabular} & 2012 & $\begin{array}{l}\text { www.plantagon. } \\
\text { com }\end{array}$ \\
\hline 9 & $\begin{array}{l}\text { Green } \\
\text { Sense } \\
\text { Farms }\end{array}$ & $\begin{array}{l}\text {-First farm } \\
\text { in : Portage, } \\
\text { Indiana } \\
\text {-Shenzhen, } \\
\text { china }\end{array}$ & & New & $\begin{array}{l}\text {-Micro Greens } \\
\text {-Baby Greens } \\
\text {-Herbs } \\
\text {-Lettuces }\end{array}$ & 20,000 sq./ft & $\begin{array}{l}\text {-Using stacking vertical } \\
\text { towers } \\
\text {-Using automated } \\
\text { computer controls, which } \\
\text { provide the precise amount } \\
\text { of light, nutrients, water, } \\
\text { temperature, and humidity } \\
\text { - Minimize waste, and } \\
\text { recycle water technique }\end{array}$ & $-\overline{2014}$ & $\begin{array}{l}\text { http://www.gree } \\
\text { nsensefarms.co } \\
\text { m }\end{array}$ \\
\hline $\mathbf{0}$ & eroFarms & $\begin{array}{l}\text { Newark, } \\
\text { New Jersey }\end{array}$ & $9 \mathrm{~m}$ & New & \begin{tabular}{l}
\multicolumn{1}{c}{250} \\
different types of \\
herbs \\
and greens grow \\
like kale, \\
arugula, and \\
mizuna.
\end{tabular} & $\begin{array}{l}\text {,000-sq/ft } \\
\text { with } 35 \text { rows } \\
\text { and } 12 \text { levels } \\
\text { of vertically } \\
\text { grown }\end{array}$ & $\begin{array}{l}\text {-Without any soil, } \\
\text { pesticides, or sunlight. - } \\
\text { Crops sit on stacked trays } \\
\text { outfitted } \\
\text { - LED lights } \\
\text {-Using Sensors that track } \\
\text { the growing process. } \\
\text { - Recycle water technique }\end{array}$ & 2012 & $\begin{array}{l}\text { http://aerofarms } \\
\text {.com/ }\end{array}$ \\
\hline
\end{tabular}


However, there is a paucity of information and a limited number of published critical reviews on Vertical farming in urban areas. This study, in order to review the major benefits and challenges, uses the framework of sustainability to realize the role of VF in prospective food provision in cities and also reviews the main advantages and disadvantages. A total of 60 documents that have been published in international sources are analyzed.

\section{METHODOLOGY}

In the current study, a systematic review was performed on previous literature on the primary research question: what are the opportunities and challenges of VF mentioned in these academic and scientific papers? The first phase consisted only of peer-reviewed papers. In the second phase, more documents such as proceedings, dissertations, projects and articles published in magazines were reviewed. Peer-reviewed academic publications from well-known databases such as Web of Science, Scopus, ProQuest as well as Google Scholar were referred to and all related literature could be accessed from online sources. To investigate a specific topic, it was searched for in titles, abstracts, and keywords from online sources between 2007 to December 2016. Subsequently, relevant papers included in the search, were perused for their relevance and eventual results. These papers were examined, explored and compared in order to identify multiple merits and demerits of VF. In order to make sure all the sources were picked up were based on the keywords, a Microsoft Excel spread-sheet was prepared.

\section{Systematic Framework and Key Concepts}

To conduct a systematic review of the literature obtained, a systematic framework was developed, to facilitate in organizing the complicated topics. This framework is rooted in the concept of sustainability as stated in the Brundtland Report, 1987 (Brundtland, 1985), in which the three bases (environmental, social and economic) share some similarities at the core of which is sustainable development. To analyze the content more extensively, a grid was constructed consisting of 26 groups of sub-topics collected from multiple papers, mostly from Bohn and Viljoen (2011). Three overall themes were extracted, namely; social, environmental and economic (Bohn \& Viljoen, 2011). A Microsoft Excel file for each aspect of sustainability was then made for each analyzed article, in case a document referred to a topic related to VF, that theme would be integrated into the file. In the statistical analysis, frequencies were used as well as comparability. Through attributing a topic to one aspect of sustainability, we accept the interaction and mutual relationship between and among all aspects too.

\section{Systematic Analysis of Sustainability Dimensions}

Table 2 indicates that the majority of the papers (47) looked into at least one issue assigned to the environmental aspect. However, 30 from among 60 sources addressed topics related to issues concerning the social aspects while 23 were concerned with issues related to economics. Most of the papers deal with issues of all of the three aspects (Table 2). 
Kalantari F., Mohd Tahir O., Akbari Joni R., Fatemi E.: Opportunities and Challenges in Sustainability of Vertical Farming: A Review

Table 2, Absolute frequencies of sustainability dimensions in the surveyed literature $(\mathbf{n}=60)$

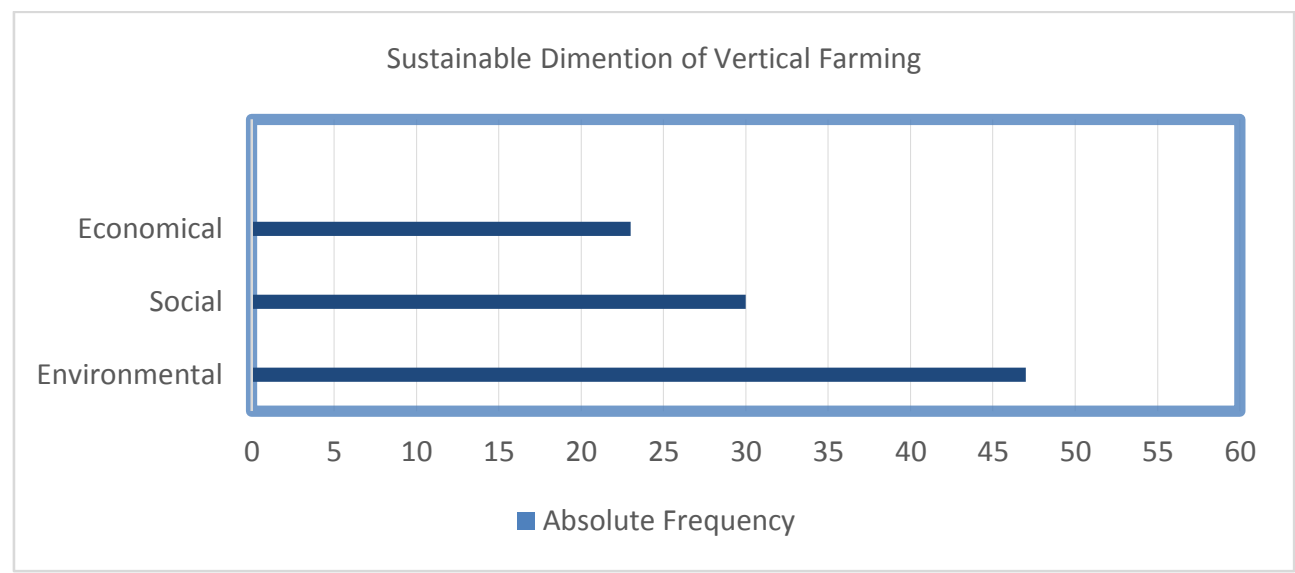

\section{Absolute Frequencies of Sustainability Dimensions}

With regards to the sustainable dimension of VF, the following tables depict the absolute frequencies of the environmental dimension (Table 3), the social dimension (Table 4) and the economic dimension (Table 5).

Table 3: Absolute frequencies of topics in surveyed literature related to the environmental dimension of sustainability $(n=47)$

\begin{tabular}{|ll|}
\hline Environmental Dimension & Absolute Frequency \\
\hline Reduction of Water Demands & 18 \\
Energy Saving & 16 \\
More Productivity Per Unit of Area & 15 \\
Healthy Food Provision & 14 \\
Reduction of Carbon Footprint And The Effect of Air Quality & 12 \\
Reduces Fossil Fuel & 11 \\
Recycling of Organic Waste & 11 \\
New Landscape Opportunities & 10 \\
Reduction of Urban Head Island & 9 \\
Protect From Natural Disease & 8 \\
Reduction of Herbicide and Pesticide Manufacture & 7 \\
More Productivity Per Unit of Area & 7 \\
Resilient to Climate Change & 6 \\
Acting As a Sound Insulator & 2 \\
\hline
\end{tabular}


Table 4: Absolute frequencies of topics in surveyed literature related to the social dimension of sustainability $(n=30)$

\begin{tabular}{|ll|}
\hline Social Dimension & Absolute Frequency \\
\hline Job Opportunity & 9 \\
Greater Community & 7 \\
Visual Amenity & 6 \\
Education & 6 \\
Improved Food Security & 6 \\
Leisure & 4 \\
Psychological/Spiritual Health & 4 \\
\hline
\end{tabular}

Table 5: Absolute frequencies of topics in surveyed literature related to the economic dimension of sustainability $(\mathbf{n}=\mathbf{2 3})$

\begin{tabular}{|ll|}
\hline Economic Dimension & Absolute Frequency \\
\hline Economic Opportunity For Land Scarcity & 11 \\
Return of Investment & 6 \\
Minimization of Energy Cost & 5 \\
Low Price of Food & 4 \\
Community Economic Growth & 4 \\
\hline
\end{tabular}

\section{OPPORTUNities AND CHALlENGES OF VERTICAL FARMing}

We proceed with a list of the primary prospects as well as challenges of VF based on the review of the literature which will be discussed along with the three aspects of sustainability.

\section{Environmental Benefits}

As for environmental advantages, farming in cities conserves biodiversity, reduces wastage and loss and curtails the energy used for producing and providing food for the public (Ankri, 2010; Perez, 2014; Thomaier et al., 2015). Dspommier (2010) however, comments that VF is not a panacea for all existing sustainability problems but can contribute significantly by providing solutions to existing problems. It can potentially replace industrial agriculture and could be a better alternative by minimizing damages caused by conventional open field agriculture. VF brings with it many ecological and poral benefits, and can, therefore, move agriculture towards the direction of agroecology. Other sectors that could benefit from VF, will be elaborated upon in the following sections.

\section{Energy Saving}

The body of research on VF has pointed out the role of greenhouses in saving and recycling energy (Specht et al., 2014), for example the system makes use of natural light, artificial light and energy to facilitate in environment management (temperature control), water provision (irrigation) and nutrient delivery (Perez, 2014; Sivamani, Bae, Shin, Park, \& Cho, 2014).

Challenges of lighting: Over two-thirds of the global energy is consumed in cities. A critical point and disadvantage often highlighted by the adversaries of VF is, how will plants growing inside a building be provided with sufficient amount of energy needed for plant growth (Al-Chalabi, 2015; Specht et al., 2014). The system make use of both natural 
light as well as artificial light as the main source of energy within the building for photosynthesis (density and exposure) and photoperiodic (time and duration) as well as the structure (dimensional light dissemination) of plants (Germer et al., 2011). Since vertical farms within buildings have less access to natural light, there is a need for artificial lighting which is often provided by LEDs, which is comparable to greenhouse farming. Nevertheless, it is an extra cost that needs to be taken into consideration (Banerjee \& Adenaeuer, 2014). As hypothesized by Perez (2014), if the agriculture industry of the United States followed a vertical approach, the electricity required for lighting would be eight times that of the amount generated by all power plants annually in the United States. Actually, taking full advantage of additional lighting in vertical farming still remains a challenge.

Another point that critics of VF usually target is, the lack of natural light source in cities. It is not plausible or practical to use solar panels for providing energy in vertical farms, due to the shade of buildings (Perez, 2014). Therefore, in the future The lack of natural lighting will be less noticeable (Specht et al., 2014).

Ankari (2010), mentioned in his study that, converting a horizontal farm into a vertical one would be challenging due to limited space. The width of a horizontal field would have to be divided into smaller portions in order to form the vertical version. However, the primary problem of growing plants this way is, limited exposure to the sun. Plants may be deprived of sunlight since many layers are stacked one above another which prevents sunshine from reaching the plants below. Even if VF were to be put into practice on a large-scale, this would not completely solve agricultural problems. Not only would plants in such a system be deprived of soil for growth, but would also be denied a key source of energy namely, natural light (Ankri, 2010).

The opportunity of lighting: The LED can be turned off and on as frequently as required for the plants. It does not adversely affect the plants while it helps to further save energy (Perez, 2014; Thomaier et al., 2015). How Photosynthetically Active Radiation (PAR) is related to conversion and biomass is important in deciding the amount of energy required for producing a specific amount of food. A relevant study conducted by NASA, identified a maximal of $12 \%$ conversion efficiency from PAR to biomass. The estimated PAR conversion efficiency they reported was, 1.6 gram of dry mass/mol, considering the control of lighting as well as an optimal enrichment of carbon dioxide. LEDs is the preferred choice as it is easily manufactured and an ideal choice of artificial lighting for plants. In another research conducted in Rutgers University, LEDs were recommended as they save electrical energy while simultaneously facilitating plant growth (Despommier, 2014; Perez, 2014). Many existing VF in the word using the LED in these technologies such as Republic VF in South Korea, Nuvege plant factory in Japan and Plantlab VF in Holland.

Challenges of Heating: An issue closely linked to lighting is, the temperature it produces. More than the brightness, lighting devices produce heat, which especially in summer would disrupt or interfere with the air conditioning system. Two other crucial requirements for healthy plant growth indoors, are humidity as well as air conditioning which require meticulous control and monitoring and involves high energy costs. Still another major prerequisite and cost is in the building of the towers. The feasibility of these towers remains questionable, especially problems related to the amount of energy required for lifting artificial growth equipment, water or other resources such as fertilizers high onto the towers or moving them down when necessary (Ellingsen \& Despommier, 2008).

Opportunities of Heating: Thomaier et al. (2015), suggest that the greenhouses can be creatively used as a source of energy production, whereby excessive energy produced can be used to heat up the building itself. The problem however, is that this innovative proposal has yet to be publicized (Thomaier et al., 2015). Additionally, another advantage of growing 
plants indoors is that they keep the air around them and in the vicinity cool. This phenomena occurs through a process of evapotranspiration, when plants absorb water from the soil, which is then transferred to the plant body and leaves and is eventually released into the air, which consequently brings down the surrounding temperature. Another way plants help to cool the surrounding environment is through providing shade if they are large enough. In large buildings, the atrium functions as a means to adjust the temperature inside the building (Afrin, 2009; Thomaier et al., 2015). It was also reported that, a hydroponic vertical garden managed to cut down on the amount of energy used in a tall building up to $23 \%$ and reduce the air conditioning up to $20 \%$ (Specht et al., 2014).

Thus, VF involves sustainable energy sources and power can be sent back to the grid. Furthermore, other means by which VF saves energy is in reduced transportation, temperature reduction, power saving, reduction in processing and packing as well as renewal energy among urban/local areas and industrial or agriculture areas. This can be manifested in how they utilize surplus heat, cooling water and carbon dioxide from the industrial sectors in greenhouses (Ahlström \& Zahra, 2011; Cicekli \& Barlas, 2014; Miller, 2011; Sauerborn, 2011).

\section{Reduction of Water Demand}

Challenges of Water Demand: It is estimated that approximately, 3000 liters/person/day of water is regularly used in Europe just for producing food (Perez, 2014). Out of the total water consumption of human beings, $24-30 \%$ of it is used for watering and producing rice (Germer et al., 2011).

A key factor in this system is the transport of water especially high loads to higher floors in tall buildings (Perez, 2014). The transport of water is essential not only in providing the required water supply in the building but also in managing the sewage system like in any industrial building. In addition, the water source will aid in supplying nutrients needed for various crops within the main irrigation system. The fluid provision system needs to be standardized both in the growing floors as well as the others, exactly like an industrial unit (Banerjee \& Adenaeuer, 2014).

Opportunities of Water Demand by Recycling and Dehumidifying: Perez (2014), believes that the determining factor which makes it possible to build a VF or not is the water supply (Perez, 2014). Producing food is not the only application of vertical farms, but it can also help in recycling the city's water supplies (Ellingsen \& Despommier, 2008; Lam, 2007). As part of an initiative plan suggested by Despommier (2010), instead of releasing wastewater into rivers, it can be used for VF irrigation, where the wastewater is purified and recycled and water drainage will not be necessary. So, the gray or black water can be purified in vertical farms and converted to drinkable water through evapotranspiration (Banerjee \& Adenaeuer, 2014; Besthorn, 2013; Cicekli \& Barlas, 2014; Despommier, 2009, 2010; Sauerborn, 2011; Thomaier et al., 2015; Voss, 2013). Green Sense Farms in Indiana and AeroFarms in New Jersey are using this technique to recycle water in their vertical farms.

Opportunities of Water Demand by Aeroponics and Hydroponic Systems: The best and most efficient method of water consumption in farming is facilitated through two systems namely; aeroponics and hydroponics. If used together in closed loop systems, it can manage to save water up to $95 \%$. They can also help to eliminate farming wastewater which is potentially hazardous to the environment and to human health (Despommier, 2010; Germer et al., 2011; Voss, 2013). As described by Toyoki Kozai, the manager of the NPO factory, when the air is dried and water is circulated back with the help of aeroponics and hydroponics, the efficiency of water consumption goes up to $97 \%$ as compared to traditional agriculture. Thus, the amount of water consumed in VF for irrigation is only $3 \%$ that of the 
Kalantari F., Mohd Tahir O., Akbari Joni R., Fatemi E.: Opportunities and Challenges in Sustainability of Vertical Farming: A Review

amount used in conventional farming. Sauerborn (2011) states 10 hectares of agricultural field can be substituted by a hectare of a greenhouse recirculating hydroponic system (Sauerborn, 2011; Specht et al., 2014). In addition, a recent study on water consumption in VF conducted by Despomier (2010) indicated that, new vertical farms used $98 \%$ less water than traditional farms (Despommier, 2010). In the Den Bosch project, almost all types of crops have been produced through VF with $90 \%$ less water consumption than traditional farming (Besthorn, 2013). This amount was reported to be $70 \%$ in another study. Despomier (2013) also stated that, less water (70-80 \%) is assumed to be used in VF as compared to conventional farming techniques (Despommier, 2011, 2013). Hydroponic and Aeroponic systems are using vastly in many existing VF projects such as Sky Greens Farms in Singapore, Nuveg plant factory in Japan and Planned Vertical Farm in Sweden.

\section{More Productivity Per Unit of Area}

Opportunities: Crop production can increase drastically if full-year stability is maintained during production, by implementing efficient methods during the process (Banerjee \& Adenaeuer, 2014; Despommier, 2011, 2013; Miller, 2011). The key difference between VF and traditional farming is in the variety of products that can be produced at a given time. In traditional farming, only one crop at a time can be produced, which is referred to as monoculture, whereas in VF, multiple types of crops can be produced simultaneously on different floors. Another advantage of VF is, that unlike traditional farming which can only be carried out at a particular time of the year, plants inside a VF can grow all the time throughout the year (Platt, 2007; Sivamani et al., 2013). Therefore, fewer crops are lost as compared to conventional agriculture. It is difficult to quantify space efficiency in a closed environment for farming because some types of plants have a better harvest than other types of plants in comparison to others (Ellingsen \& Despommier, 2008).

This was further demonstrated in a study carried out by Perez (2011), where they reported that products harvested annually through VF amounts to 470 tons per acre, and 23 times more lettuce is produced by VF than in the same amount of space in conventional farms (Cicekli \& Barlas, 2014; Perez, 2014). Thus in VF, space is utilized more efficiently, each closed-space acre is equivalent to 4-6 acres of open field depending on the type of crop. For instance to grow strawberries, an acre of land that is required for a closed space, would require 30 acres of open space (Ahlström \& Zahra, 2011; Banerjee \& Adenaeuer, 2014; Despommier, 2010, 2013; Voss, 2013). According to Besthorn's (2013) report, three times more crops were produced in the Den Bosh VF project than traditional farming methods (Besthorn, 2013). Therefore, if the available space in the greenhouse is doubled or tripled, the amount of crop production will further increase (Despommier, 2014). In addition, another advantage of VF is that up to eight types of crops can be harvested yearly, in the case of hydroponically grown leafy vegetables such as lettuce, spinach, kale, and basil. However in conventional farming, only a maximum of three crops can be harvested in a year (Despommier, 2013; Eigenbrod \& Gruda, 2015). In summary, VF can therefore make use of all these advantages to provide more food in the least amount of time.

\section{Recycling of Organic Waste}

Challenges: A lot of waste is generated in buildings including, wastage of heat, gray water buildup and so on. Agricultural run-off is one of the major sources of contamination in the world today (Ellis, 2012).

Opportunities: One way of recycling organic waste is through applying a no-input system that yields a closed loop, concerning the recycling of waste, which would help drastically cut down on pollution (Besthorn, 2013; Despommier, 2013; Ellingsen \& Despommier, 2008). 
Waste from animals, plants and even from food manufacturing industries or houses can be a source of organic material. As production is a process that continues throughout the year, in case of a water shortage crisis, the waste water can be utilized as well as the nutrient contents and organic waste (Ahlström \& Zahra, 2011; Albajes et al., 2013). If nutrients and organic wastes from wastewater can be effectively harnessed, then there would be no shortage of some vital minerals such as phosphorus. This would consequently, minimize the number of landfills which would subsequently reduce the amount of methane diffusion and also help decrease the vermin population such as rats and cockroaches (Despommier, 2010; Ellingsen \& Despommier, 2008).

Numerous ideas for waste management in VF have been presented in previous literature. The studies have sought to optimize or possibly close the cycle of nutrients sometimes at a small scale for example in a building, and sometimes at a larger scale for example, in an entire city. Compost has already been widely used in cities in an attempt to recycle organic waste. Conversely, there are mixed farms that close the cycle of nutrients by applying aquaponic vegetable mixtures, aquaculture, vermiculture along with vegetable systems and city fisheries that utilize the sewage and waste water as food (Specht et al., 2014). For example, 300 kilocalories of energy resides within an ordinary amount of human excrement which is equivalent to about half a pound, when used in a bomb calorimeter. If we assume that there are eight million residents in New York City, we can infer that approximately, 100 million kilowatt hours of electrical energy can be annually obtained from just bodily waste. This amount of energy is adequate for managing farms with up to 30 floors. Therefore, if the copious amounts of waste that is produced can be converted into energy or water, it would greatly facilitate city life (Despommier, 2009). The Plant Vertical Farm in Chicago and the Republic of South Korea VF factory are recycling their waste for using the energy.

\section{More "Land Use"}

Opportunities: If agriculture is moved indoors to form vertical farms, it will not only save space but will also provide a variety of food products, and crop output per acre of land will be maximized. Therefore, it is not just the horizontal space that can be used effectively as in traditional farming. The biggest advantage of VF over conventional farming is that it is not restricted to one plane (Banerjee \& Adenaeuer, 2014; Perez, 2014; Voss, 2013). If outdoor farming goes indoors, there will be a 20 time reduction in land use, there will be a 1/20 ratio of improvement in land consumption or $95 \%$ of savings therefore, there seems to be no reason why not to use VF. As an instance, if one floor is added, there will be a 1/40 advantage or $97.5 \%$ of savings, as compared to only $95 \%$ of savings realized through a greenhouse. The ratio of $1 / 20$ is for lettuce production and its benefits mostly originate from plant spacing and respacing which is not possible in conventional farms. The case however, is different for tomatoes and other crops. To feed a population of 100,000, each individual would need $1 \mathrm{~m}^{2}$ of space, hence a vertical farm would need to be $100 \mathrm{~m} \times 100 \mathrm{~m} \times 10$ layers with the top floor acting as a simple greenhouse (Perez, 2014).

In big congested cities where space is a rare commodity and there are not enough parks or gardens due to a lack of space, vertical farms saves space, in big cities where lack of space is a serious issue and reason why there is not enough parks or gardens, it can be effectively employed (Banerjee \& Adenaeuer, 2014). This would drastically help to reduce the use of surface land to produce food in cities effectively. The land that is currently being used for farming can be restored to its original natural state (Perez, 2014). 
Kalantari F., Mohd Tahir O., Akbari Joni R., Fatemi E.: Opportunities and Challenges in Sustainability of Vertical Farming: A Review

\section{Resilient to Climate Change}

Opportunities: There are numerous advantages of using VF over conventional farming in land soil. In VF, all the ideal conditions required for optimum plant growth can be achieved indoors such as, heating, lighting, water, humidity, amount of nutrients and suitable settings that can all be controlled and managed for a specific crop. Because the plants will be grown indoors, the changing of seasons will have no effect on the crops. This will allow for multiple harvests during the year, unlike traditional farming which enjoys only one harvest a year. This benefit of VF highly increases production output (Germer et al., 2011; Voss, 2013). In this method (VF), the overall system design can be adjusted, to cater for the specific and unique physiological requirements of a particular plant. So, not only will the best-suited environment for plant growth be decided upon, but also the best and most appropriate and efficient equipment will be selected for in VF (Germer et al., 2011). Moreover, plants grown indoors will be protected from pests and climate change, and subsequently more crops can be harvested due to lower losses as compared to traditional farming. The utmost benefit of VF is in the ability to control all conditions required for ideal growth of a particular crop where a variety of edible plants can be grown. In these ideal circumstances, plants have the ability to grow faster and become larger which leads to an increased annual crop yield than traditional forms of agriculture. Space is efficiently utilized, where maximum gain is achieved from every square foot of space. Besides plant crops, VF can accommodate domestic animals and fowls as well (Banerjee \& Adenaeuer, 2014; Despommier, 2013; Germer et al., 2011; Perez, 2014). It means VF can establishes in any parts of the word without any limitation in related to various climate/geographical areas (Refer to Table 1).

\section{Protection From Natural Disaster}

Challenges: Change of weather has always influenced farming such as changes in temperature, water supply and photo intensity which could adversely affect crops and lead to a loss in production yield. Insufficient amount of water destroys many crops every year in many countries such as Midwest America (Banerjee \& Adenaeuer, 2014; Despommier, 2009). If artificial watering systems are used, plants will be unaffected by drought or other natural disasters and they can also benefit from the artificial heating system. Photo intensity and the duration can also be controlled so as to keep all the conditions optimal (Banerjee \& Adenaeuer, 2014; Despommier, 2011; Ellingsen \& Despommier, 2008; Voss, 2013).

Opportunities: Another main advantage of VF is that it can be used anywhere and everywhere in the world since it does not depend on soil (Despommier, 2013). The ultimate goal of VF is to provide food for the entire population of the world without having to worry about the climate changes. However, not many people are engaged in this type of agriculture. In conclusion, it must be stressed upon that VF does not aim to serve only individual persons but rather, it seeks to serve the world population.

\section{Reduction of Fossil Fuel}

Challenges: In conventional farming there is too much fossil fuel consumption, for example, in America alone $20 \%$ of these types of fuels are consumed in farming (Besthorn, 2013). Approximately, 4-8 barrels of oil is used every year by every American citizen to produce their food. A major portion is used for transportation as well as storage. Fossil fuels that are used in transportation not only cause local or global air pollution but are also harmful to human health. It is also responsible for change of weather and greenhouse gas distribution. In the process of producing agricultural crops, a lot of fossil fuel is required for plowing, seeding, harvesting, fertilizing and so on (Voss, 2013). Therefore, VF can cut down on transportation required for transporting food. 
Opportunities: When food is produced within the city, cities become places for both providing and consuming food crops. The target consumers of crops are those living near the site of production (Banerjee \& Adenaeuer, 2014). This localization attempt helps to reduce costs, pollution and many other problems (Miller, 2011). The lifestyle it promotes is 'local for local' which minimizes the route between food production and consumption (Specht et al., 2014).

In addition, as previously mentioned, since VF helps to provide food locally where it is also consumed, there would be no need for long distance transportation (Banerjee \& Adenaeuer, 2014; Germer et al., 2011). Therefore, more energy is conserved and the environment remains protected. Another problem that occurs during transportation from the site of production to the site of destination is, infestation or spoilage, which could have certain negative ecological effects (Miller, 2011). Meanwhile, $30 \%$ of food is lost due to spoilage or infestation (Despommier, 2009). In conventional farming, food is normally transported as far at 1500 miles from the area of production, VF would eliminate the need of packing agricultural crops for transportation and would thus conserve energy (Ellingsen \& Despommier, 2008; Miller, 2011).

Since there is no farming machinery (e.g. tractors, plows or inorganic fertilizers) involved in VF, fewer fossil fuels are required. No fossil fuels would be required for harvesting, freezing storage or carrying them away (Banerjee \& Adenaeuer, 2014; Despommier, 2010, 2011; Perez, 2014; Specht et al., 2014). In a VF system, everything is facilitated through robotics (Voss, 2013).

If the VF is located downtown, it would be the ideal location as it would be close to the major retail outlets. There would be no need for transportation, as immediately after harvest the food products can be sold in the shops (Voss, 2013). Specht (2014) states that this to be the response of high technology to transporting local foods (Specht et al., 2014).

\section{New Landscape Opportunities}

Challenges: A key problem that exists in the current method of farming, is the amount of land that is needed. Currently, for the purpose of agriculture, millions of hectares of natural land is converted into farmlands. It has severe detrimental effects on nature, the herbal ecosystem, and biodiversity. So far great damages have been made to wetlands, meadows, tropical forests, which in some cases have led to a total loss of these resources (Voss, 2013). Such examples of total loss are rainforests in the Amazon basins and destruction of ground water in the Khorezm basin (Banerjee \& Adenaeuer, 2014). Since almost half of the earth's land is used for farming (and is ever increasing), such research findings can help to support the argument in favor of nature restoration. When too much land is being allocated for agriculture, it could seriously affect the earth's capacity to accommodate human beings on it (Germer et al., 2011).

Opportunities: A great benefit of VF is that it gradually helps in repairing the land (Voss, 2013), large parts of the ecosystem are restored as a result. When VF and all its common forms become the norm and replace conventional farming techniques, most vegetables, fruits and food products will be produced through VF and subsequently many of the fields that are currently devoted to farming may be restored to their original state (Despommier, 2013). Consequently, many parts of the damaged ecosystem can be revived (Despommier, 2010, 2011; Ellingsen \& Despommier, 2008).

In most cases it is enough to leave it to nature to revive and restore itself with time (Voss, 2013). A sustainable environment can be achieved for urban centers through VF (Despommier, 2010). When fields are saved from farming, trees will once again become an integral part of city life, which will help reduce the amount of carbon dioxide and improve 
Kalantari F., Mohd Tahir O., Akbari Joni R., Fatemi E.: Opportunities and Challenges in Sustainability of Vertical Farming: A Review

the atmosphere (Despommier, 2014). The protection of biodiversity will lead to an increase in genetic varieties of plants and animals (Ahlström \& Zahra, 2011) and the reduced stress on the land will help natural ecosystems flourish (Germer et al., 2011).

\section{Healthy Food Provision}

Health is related to the food we consume, and the consumption of locally produced food is related to improve overall health. Health is mostly guaranteed by the 'freshness' and wholesomeness of food. According to Miller (2011), health is affected by the local, organic food produced by VF (Miller, 2011).

Challenges of Food Nutrition: Foods rich in vitamins, proteins and minerals are increasingly in demand nowadays, as more countries are moving towards the trend of their developed counterparts. Contrary to Engel's law which perceives a negative correlation between spending on food and higher income, the consumption style of such countries is changing.

Another common problem that exists among many developing countries is the use of human or animal feces instead of artificial fertilizers (Despommier, 2010) for farming. Although fecal matter is an effective fertilizer, it also comes with some unfavorable factors, such as parasites, infection, and disease.

Opportunities of Food Nutrition: The advantage of vertical farming is that it has the ability to reduce the threat of these infectious diseases since it does not use fecal matter as a fertilizer like in conventional agricultural techniques (Despommier, 2010; Ellingsen \& Despommier, 2008). Therefore, it helps to stop the transmission of such harmful infectious diseases. In environments polluted with fecal matter, many viral or bacterial diseases can potentially endanger the lives of 2 billion people. However, this is mostly avoided by implementing VF (Despommier, 2011, 2013; Graff, 2009).

An advantage of locally-produced foods is, that it is really fresh when it reaches the customer, and consequently the nutritional profile is much better (Despommier, 2010, 2011; Specht et al., 2014; Voss, 2013). VF also helps to produce organic fish rich in protein with the use of aquaponic systems. Traditional production of protein rich food was conducted on a minute scale and was mostly vegan or vegetarian based which was carried out if the neighborhood and infrastructures could accommodate it. VF however, is a means to a healthier alternative for the people. The goal of VF is to provide healthy, local food which is affordable for everyone (Miller, 2011).

Challenges of Laboratory product: One of the drawbacks of the idea of VF is that visitors might perceive it as similar to a laboratory. The appearance might give the impression that some genetic engineering is taking place and the products are far from natural. However, in reality, the place provides for a healthy growth of crops void of any pollutants or pesticides which is not possible outdoors.

Also, a key obstacle to public acceptance of VF is, the soil-less production technique. People find it hard to accept and are crucial about this new idea and its products. Many avoid buying these products and prefer to buy natural soil-based crops (Specht et al., 2014).

Opportunities of Laboratory product: According to Despomier (2010) VF has many environmental benefits. Less energy is consumed and less toxicity is produced when food materials are cultivated indoors than outdoors (Despommier, 2010). He states that, natural landscapes are not appropriate for agricultural products. He further suggests that, since skyscrapers are expensive to build and were constructed at the cost of the environment and ecology, why not use them for agriculture? It is also much more feasible to control various conditions indoors and is void of infections, pests, and bacteria (Voss, 2013). New roles 
should be assigned to agrochemical industries to design safer chemicals for sustainable crops (Despommier, 2010).

Moreover, VF enjoys many privileges over conventional agriculture. Since these products are not soil-based, they are not affected by polluted soil or polluted irrigation water and are therefore much safer. Crops produced by VF are environmentally friendly, rich in nutrients, safe and fairly made (Besthorn, 2013). Less burden is placed on the environment since there is no nitrogen $(\mathrm{N})$ and phosphorous $(\mathrm{P})$ runoff into natural water sources (Germer et al., 2011).

\section{Reduction of Urban Heat Island}

Challenges: An increase in temperature especially in cities is caused by the absorption and re-radiation of solar energy, which results in the formation of an urban heat island which stands as a crisis. As a key human comfort criterion, temperature both, affects and is affected by people's lifestyle. Urban heat island is defined as the maximal temperature difference between city and country areas (Safikhani, Abdullah, Ossen, \& Baharvand, 2014). As reported by the UN, cities account for $75 \%$ of all energy depletion as well as $80 \%$ of the globally distributed greenhouse gases (Banerjee \& Adenaeuer, 2014; Säynäjoki et al., 2013). For every 1 unit of temperature increase, $10 \%$ of cultivated land is reduced due to the effect of climate change (Glaser, 2012).

Opportunities: One effective way of reducing city temperatures is the use of green areas inside cities. Since research has shown that green areas designed at a particular distance from each other can cool the environment, there is a direct correlation between temperature and greenery (Nochian et al., 2015). It has also proved to be effective against the urban heat island phenomena as it helps to enhance the city microclimate (Ahlström \& Zahra, 2012; Cicekli \& Barlas, 2014; Safikhani et al., 2014; Tan et al., 2015; Thomaier et al., 2015). Observational studies have reported that green parks in cities were 1 degree cooler than the other parts of the city which were not vegetated. Recommendations for new urban designing projects in Hong Kong have included 20-30 \% of green areas to enhance the urban quality of life (Tan et al., 2015). Afrin (2009) has suggested the use of cool and green roofs for their indirect role in lowering carbon dioxide emissions of power plants as well as lowering the temperature during severe conditions in summer days (Afrin, 2009). It is very challenging however to abide by this standardized green coverage requirement in cities due to the extensive use of city land for buildings and infrastructure (Tan et al., 2015).

In conclusion, VF manages to lower urban temperatures through the use of vegetation. It can consequently reduce heat islands and the overall temperature of buildings too (Banerjee \& Adenaeuer, 2014).

\section{Acts As a Sound Insulator}

Opportunities: Yet another benefit of VF is in the management of noise, they can act as obstacles to noise disturbances since they are able to lower sound reflection. Soil, vegetation and air confined in VF acts as a sound insulator (Safikhani et al., 2014). In an investigation conducted by Afrin (2009), they concluded that indoor sound can be lowered up to 60 decibels by green roofs, because much of the noise produced by traffic, planes, machinery, etc. is absorbed by green roofs. Plants are capable of absorbing higher frequencies of noise (Afrin, 2009).

\section{Reduction of Carbon Footprint and the Effect on Air Quality}

Challenges: As air quality continues to worsen, it has become a cause of serious concern in cities all over the world (Afrin, 2009). Up to $70 \%$ of the world emission of carbon dioxide is 
accounted for by cities, nowadays. Moreover, health risks associated with polluted food products either due to contaminated air or water sources, is of utmost concern since it originates from untreated wastewater (Kalantari, Mohd Tahir, Golkar, \& Kalantari, 2015).

Opportunities: A key advantage of VF is providing a sustainable environment in city centers by cleaning the air and providing an access to greenery which has positive mental effects on people (Ahlström \& Zahra, 2011; Banerjee \& Adenaeuer, 2014). People living in cities are often subjected to high levels of $\mathrm{CO}_{2}$, they are exposed to high levels of carbon in the soil and a reduction in main functions of an ecosystem (Germer et al., 2011). If an ecosystem regrows, then nature's ability to protect itself will also increase as well as its adaptability and strength against disturbances and pollution. Reviving the key functions of an ecosystem is the key to reversing the negative effects of climate change, it can potentially lead to a clean and less contaminated future (Despommier, 2010; Miller, 2011; Vogel, 2008). According to the findings of Afrin (2009), 4000 kilograms of air particles can be reduced by 2000 square meters of uncut grass on roofs, by trapping it in its foliage. According to numerous reports, plant coverage can trap particles in air and dissolve them. It can also trap gas pollutants especially carbon dioxide by means of the stomata of the leaf. The trapping and dissolution of air particles is dependent on the type of plant, the season, duration of daylight and so on. This model is at present under investigation in Toronto (Afrin, 2009).

It can be concluded that, the extensive use of farming in a controlled environment inside cities and the inclusion of vegetation in skyscrapers can positively affect the weather (Despommier, 2013) as well as cause small or large scale changes in climate, the environment and eventually improve the ecology (Afrin, 2009; Liu, 2014).

\section{Reduction of Herbicide and Pesticide Manufacture}

Challenges: The frequency with which mineral fertilizers are used has increased several times since its use between 1960 to 1990 . It has led to the depletion of surface water, pollution of underground water and distribution of greenhouse gasses along with other detrimental environmental effects. Furthermore, phosphorus which is limited in supply and is extracted from mines will continue to increase in use up to the year 2030. However, there is no strategy to produce food with the least amount of phosphorus (Germer et al., 2011). We cannot do without pesticides which are inevitably employed in many situations and farmers cannot control these parameters. The only way to control the use of pesticides, is to use expensive chemical materials, high-risk food products and also get crops insured. VF aims to provide solutions for many of these problems (Banerjee \& Adenaeuer, 2014).

Opportunities: The entire process of VF is carried out in an organic manner. An advantage of vertical farms is that they significantly lower or omit the use of these chemicals and try to find natural solutions for problems, for example, by utilizing useful insects. As previously mentioned, all vertical farms benefit from controlled contexts and are void of any hazardous pests (Despommier, 2010, 2011; Ellingsen \& Despommier, 2008; Germer et al., 2011; Sauerborn, 2011), therefore, there is no need for pesticides. In VF there is no need for burning fields, grass or waste for pest control, other methods of pest control can be employed.

\section{Social Benefits}

The major goal of VF is not only to improve farming but is also a means to serve society, by bringing people closer together and closer to nature. Therefore, while providing food it also educates the people (Ahlström \& Zahra, 2011). The various aspects of the social benefits of VF will be elaborated upon in the following section. 
1. Psychological/Spiritual Health

Opportunities: Communication with nature has proved to positively influence human mental health. Moreover, being close to nature helps to reduce stress and improves obesity (Safikhani et al., 2014).

Communication with nature is believed by some researchers to be as important and necessary as interaction with other human beings (Kaplan, 1993). Furthermore, all factors that act as barriers to such a significant interaction with nature contributes to stress as we are more and more dissatisfied with the community to which we belong. Research findings have attested to the relaxing effect of observing nature on human beings especially drivers. Some other studies have indicated that people prefer enjoying natural scenery over hectic images of cities and streets. They tend to enjoy the proximity to nature either by watching it through a window or walking through it. They found that it relieved their job-related stress and contributed to better concentration at work. Some other studies reported that, children afflicted with attention Deficit Disorder tend to show improvement after playing for some time in a green park as compared to those that have no access to nature. Numerous studies have demonstrated the positive effects of proximity to nature by improving a person's focus, creativity, stability, lowering stress and promoting a positive self-perception and self-value. In summary, closeness to nature has a significant positive impact on mental health (Afrin, 2009).

\section{Job Opportunities}

Opportunities: Another advantage of vertical farms is the job opportunities they provide in cities (Cicekli \& Barlas, 2014; Despommier, 2010, 2011, 2013; Miller, 2011) as limited job vacancies is a serious issue in many big cities. Not only are direct jobs involved in the vertical farm provided, but indirect job opportunities are provided as well. The main jobs involve working on these farms making, protecting and managing the entire farm structure (Besthorn, 2013). Others jobs include; managing seed production, transplant of seedlings in the VF, managing resources ranging from water to light, machinery, etc., supervising the growth of plants, pollination techniques, harvesting, managing waste, managing energy, quality control (based on lab surveillance of plant pathogens as well as pest control), distribution control, managing IT personnel and other human resources. These are only some of the work opportunities involved in the food production industry related to VF (Despommier, 2013). Once the foundation of VF is established, society outreach, instruction provision as well as a business center can also be considered (Despommier, 2014). Moreover, VF also includes grocery stores, food markets, and local distribution centers which provide other work-related opportunities (Besthorn, 2013; Despommier, 2009).

\section{Visual Amenity}

Opportunities: Design and application of vertical vegetation systems dates back to the famous Babylon hanging gardens. Since ancient times, people used plants inside their buildings or houses to obtain relaxation and relief from them as well as for aesthetic reasons, it provided them with a sense of closeness to nature (Safikhani et al., 2014). Therefore, it seems to be a natural instinct in human beings to desire being close to nature (Specht et al., 2014). VF and its inspiration not only contributes by providing solutions for the challenges of agriculture in cities and plantation systems related to buildings, but it also affects the perspective of what 'natural' means (Miller, 2011). For instance, possessing greenery is not only beneficial to the owner of that building (since it adds to the value of that estate) but is also serves the entire society as everybody enjoys the view and the healthy consequences. Beauty is a social asset and is not transactional. Although an owner of the building can raise 
Kalantari F., Mohd Tahir O., Akbari Joni R., Fatemi E.: Opportunities and Challenges in Sustainability of Vertical Farming: A Review

the price value of his/her building because of its greenery, they cannot charge others especially neighbors for enjoying the view (Afrin, 2009; La Rosa et al., 2014).

\section{Education}

Opportunities: It is very probable in developed countries to provide educational facilities through VF, providing information on ideas and methods of food production and use. VF acts as the link between the producer and customer (Specht et al., 2014).

The existence of vertical farms in a society provides a good platform for educating people on nutrition and health. Since currently, the foods we receive and consume come from fields outside the city, little is known about how they are produced, transported and finally arrive on our dining table. If the food we consume is produced in the cities as realized by VF, it will provide opportunities for educating people on all the procedures involved (Ankri, 2010; Thomaier et al., 2015). This makes an urban farm a place for innovative ideas, a place for teaching and learning. Coordination between farms and schools can bring the understanding of nature to the education system (Specht et al., 2014). Novel ideas for producing food and sustainable ways of structuring city life and consumption patterns are now realized in a number of vertical farms. These initiatives are often carried out and supported by research institutes as well as private organizations. In order to advertise and promote their concepts and attempts, they usually let the public view their work. This is done through arranging visits or tours to their sites. This public access would increase their knowledge of vertical farms and keep them involved in these plans (Thomaier et al., 2015). One such initiative is carried out by Gotham Greens in New York, where, visitors are voluntarily invited to visit the farms. When people visit, they will share their knowledge with others and consequently the knowledge will spread and result in further participation. A well-known example is the Science Barge greenhouse in New York which is both a greenhouse and an educational center producing vegetables. It is open to school students and any visitors throughout the year (Specht et al.,2014). The value of VF lies in connecting people to nature, otherwise the mere production of food can be served by any form of agriculture. People should be familiarized with how their food is manufactured, where it comes from, how it is raised and eventually processed (Miller, 2011).

\section{Leisure}

Opportunities: Leisure is one key aspect of the quality of city life. Plant-covered land is an appropriate place for amusement, joy, and rest (Safikhani et al., 2014). No matter where they are located on top of houses, malls or mixed areas, vertical farms can serve as sites for rest, joy, amusement and food provision. Residents of buildings can have access to an oasis close to them. These farms are usually founded by real estate owners who wish to enhance their property and invest in and benefit from their green and sustainable buildings. Other times they are established by businessmen who want to improve their working staff's work environment. Their products are mainly for personal consumption or to supply a cafeteria working with them. The foremost function of $\mathrm{VF}$ is to provide a recreational purpose to improve the quality of social life and a to increase well-being in a society (Ellingsen \& Despommier, 2008; Thomaier et al., 2015).

\section{Greater Community}

Opportunities: Most of the city-related agricultural literature emphasizes the notion of linking people to nature through connecting them to the land by gardening for example, or making communal and public places around gardens or forming groups focused on growing useful and beautiful plants (Miller, 2011). Other advantages of farming landscapes consist of 
all benefits associated with open air and images of the country life and its culture (Kalantari, Mohd Tahir, Golkar, \& Ismail, 2015; La Rosa et al., 2014). Overall, VF demands high cooperation and public participation since it involves people producing their own products (Besthorn, 2013).

VF allow for farmers and advocates to work together closely and commit to a common goal, this forms a direct connection between food production and use. VF is environmentally friendly since it minimizes the distance between food production and consumption while simultaneously maintaining the joy of it (La Rosa et al., 2014). Those who work in vertical farms share the joy of selling their goods directly to customers. Higher satisfaction is also experienced by vertical farmers when they sell their products to close friends or acquaintances whom they have known for a long time (Besthorn, 2013).

\section{Improved Food Security}

Opportunities: Food movement in developing countries is different from developed countries and so is the issue of food security. Since the main aim of VF is food provision in low-income countries, it can greatly contribute to the local basic food needs (Cicekli \& Barlas, 2014). In the cities of developed countries, other social benefits are also considered while in developing countries it is not a priority anymore. In cities, the population of consumers is very high and there are more poor people in this population too who have limited or no access to fresh food (Lam, 2007; Sauerborn, 2011). If the existing tall buildings with numerous floors are incorporated with greenhouses, they can produce the food required by the entire population of the city (Despommier, 2010; Germer et al., 2011; Specht et al., 2014). Depending on the number of floors of the vertical farm, the area of land devoted to farming and consequently crop yield will be multiplied. The concept of the VF project is in the evolution of urban structures while abiding by ecological rules. In New York City, it is estimated that a tall building which is 30-storey high is able to provide food for 50,000 citizens (Despommier, 2009; Wagner, 2010). According to these estimations, a vertical farm which requires one square block of the city and has 30 floors (about three million square feet) can provide 2,000 calories a day for each person and can, therefore, cater to the needs of 10,000 individuals (Despommier, 2010). VF was used in Israel, as reported by Ankri (2010) who reported that, 12.5 people could be fed per day by 1 acre of open field, while 97 people a day could be fed by the products of the same area of land indoors (Ankri, 2010).

\section{Economic Benefit}

The use of VF can bring about significant positive economic improvement especially in (sub) tropical countries (Afrin, 2009; Despommier, 2010). Currently, contrary to globalization, the concept of a highly adaptable and local economy has attracted a lot of attention. A manifestation of this local effort is VF in cities. An example is Singapore, an urban island country which has observed changes in the global market and has therefore set new goals and have focused their attention towards VF so as to decrease their dependency on foreign countries. The numerous economic benefits of VF will be elaborated on in the following section.

\section{Minimization of Energy Cost}

Challenges: According to the conclusion drawn by this study, VF is possible if certain ecological and energy consumption issues are taken into account, however, there is still a need for economic analysis. The initial costs and energy required to construct VF are considerable and is a fundamental problem and the possible reason why more vertical farms are not seen everywhere (Perez, 2014). Products need land, lighting, $\mathrm{CO}_{2}$, and water, which 
are all provided by nature itself, however, in VF, in order to acquire these, they must be 'purchased' (Banerjee \& Adenaeuer, 2014).

Opportunities: Maintaining VF involves certain high costs too, however, cutting down on costs can be carried out by implementing innovative strategies, such as using the building waste itself, using compact piece of land and depending on volunteer workers. Another way to cut down on costs is to integrate vertical farms in the current infrastructure, by sharing temperature, electricity, and finances (Miller, 2011). Amongst the numerous benefits of VF, one is the ability it has to decrease heat and decrease the overall costs associated with energy use (Safikhani et al., 2014). When less energy is consumed, the price of energy will be affected too. It is evident that if energy consumption is lowered in VF, low prices will follow too.

Despomier (2009) finds that location is closely related to this issue. In many parts of the world including Iceland, Italy, New Zealand, South California and east Africa, they make use of geothermal energy source. In order to get the most out of sunlight, especially in desert areas where there is abundant sunshine (for example Southwest America, Middle East and many parts of Central Asia), 2-3 floor structures are used ranging from about 50-100 yards in width or miles in length for their crops. Lands that have the privilege of steady winds (seaside and the Midwest) could absorb and harness that energy. A common practice everywhere in order to produce electricity, is the burning of plant waste which is converted into electricity or fuel (Despommier, 2009).

\section{Community Economic Growth}

Opportunities: As for economic benefits, moving food production into the cities is thought to carry with it public advantages and outcomes (Miller, 2011; Specht et al., 2014). Food is an integral part of the city economy, all food-sale centers such as restaurants, cafeterias, fast food shops, supermarkets, wholesale markets or retailers, depend on food and comprise urban economy. As a result, including local food production into the system is demanding but at the same time rewarding for urban areas. Producing food inside cities is a kind of agricultural capital and VF can be set up in public or private buildings. Specht et al. (2014) maintains that traditional views of urban or country models should be transformed, so should the wrong assumption that there is no space inside cities for farming (Specht et al., 2014). There are commercial farms which work just for profit but if they were accompanied by commercial kitchens, more valuable food products could be provided and sold in markets (Hui, 2011). Although farming indoors is associated with large production yield and is expected to be run by professionals, a variety of methods of distribution can exits. In order to cut down on agricultural economics, organizers could be private corporations, credible communities or local governments, hiring people to manage all the procedures. It would be interesting to form social networks among producers, farmers, and consumers, as well as rural and urban producers (Specht et al., 2014).

\section{Low Price of Food}

Challenges: Since food price is closely linked to oil price, fossil fuel consumption is an influential factor. A rise in the price of oil is followed by an increase in the price of food. However, oil resources and fossil fuels are getting scarce.

Opportunities: For local food, it is very efficient since food materials produced locally need not be transported to their destination (Despommier, 2009; Ellingsen \& Despommier, 2008). Foods usually have to be transported long distances before they are consumed. In VF, large amounts of food are produced at a low cost of fuel or transportation. The cost is so low that it overshadows the real environmental and social benefits of it. This is accompanied by 
continuous production which breaks the price shock in the international crop market (Germer et al., 2011).

\section{Return of Investments}

Challenges: In VF, there is a need for huge investment for the nutrient delivery systems, platforms for growing crops and growth equipment, which would significantly raise costs. This high investment seems to be a disadvantage when compared to traditional farming methods (Banerjee \& Adenaeuer, 2014) but although high costs prevent public reception, it does not prevent corporate benefits. It is undeniable that some costs can somehow be reduced but some costs cannot. If VF is of a large-scale type, the investment process becomes very intensive (Miller, 2011).

Moreover, the location chosen for VF is a key factor as the price of land influences decisions (Perez, 2014) especially due to the high price of land in cities (Ahlström \& Zahra, 2011). This price issue is particularly important in cities and should be considered carefully before it turns into a potentially serious problem (Voss, 2013).

Opportunities: The initial costs of setting up, equipping and operating a vertical farm is undoubtedly very high and is mostly due to energy use. As time passes, these costs are reduced, especially those related to energy provision. Therefore, though it is known that setting up vertical farms is very costly, to begin with, when it is running and fully functional, the price of food will come down (Abel, 2010).

As argued by Despommiers (2009), in every city there are numerous appropriate sites for such projects and if used effectively, they can return and circulate a lot of money back into the city (Despommier, 2009). The author believes that though it seems very trivial, evaluating all the conditions on every level is required, so as to thoroughly assess all the possibilities when deciding upon establishing a vertical farm (Voss, 2013).

Moreover, the idea of VF is a promising move towards the right direction for fans of the revolutionary resource-based economy movement. Economic analysis as well as investigations of the effects of VF on post-industrial cities is needed. Further discussion and analysis is required on the implications of VF on urban life all over the world (Miller, 2011).

\section{Economic Opportunity for Land Scarcity}

Challenges: Available and accessible land is a key issue in food production in cities and a major concern in setting up VF is finding an appropriate space within the city. Localization is the main goal of VF and that is localizing food production (Sivamani, Kwak, \& Cho, 2014; Voss, 2013). Open space is hard to find in many cities, and when there is a dearth of space in the production unit, certain technologies can facilitate, those that are specialized for limited spaces (Dubbeling, 2011).

Opportunities: Critics who doubt the feasibility of the concept, tend to focus on the high costs of properties in expensive cities such as New York, London or Paris, and doubt how it will ever be economically feasible in in such contexts (Despommier, 2009; Eigenbrod \& Gruda, 2015). Land is expected to become more and more scarce in the future both in cities and the countryside, however, VF does not intend to seek additional land for its purpose. Instead, it intends to make use of pre-existing unused areas in cities, for example, empty and unoccupied buildings. It involves innovative ideas for renewing old unused buildings to adapt and transform them into indoor farms (Cicekli \& Barlas, 2014; Ellingsen \& Despommier, 2008; Thomaier et al., 2015). Building in the city center might not be affordable, but there are many other areas left in the city that can accommodate and would encourage such projects. There are usually many empty, abandoned and unused buildings located within and around cities (Despommier, 2009; Kim et al., 2014). The issue of land and 
Kalantari F., Mohd Tahir O., Akbari Joni R., Fatemi E.: Opportunities and Challenges in Sustainability of Vertical Farming: A Review

food security can be redefined by VF in populated cities when food production is added to the city building stack (Thomaier et al., 2015).

A survey of New York's 5 boroughs, that was conducted several years ago, discovered as many as 120 deserted buildings which could be potentially revolutionized. These buildings could be turned into vertical farms to serve the needy inhabitants of those parts of the city. There are infinite number of such sites all over the world as well as available number of rooftops everywhere (Despommier, 2010).

\section{CONCLUSION}

We can conclude that even a little knowledge and awareness of VF can help food security and viability greatly. New technologies such as aeroponic systems, insulation methods and pest free plant growth has not only transformed the greenhouse industry but has also paved the way for new forms of farming such as rooftop farming. In apartments and office buildings, creative climate management technologies and natural light management technology helped to save energy and cut down on greenhouse gas distribution (Germer et al., 2011). These have all made local food production in highly populated city areas possible, where more people require more food and their needs cannot be met (Thomaier et al., 2015).

VF has got numerous advantages over traditional farming, which includes more efficiency, adaptability, and environmental benefits, which is all made possible through carefully controlled systems of VF. In VF, no waste or pollution is involved, it enjoys high levels of potentiality. All the above-mentioned benefits in a single system seems rather unbelievable, but VF has made it possible. If its use becomes common and widespread across the globe, the fear of starvation will also disappear and detrimental climate change will slow down too. Practically all famous Vertical Farms were situated in cities with more than 150,000 populations. Europe and North America have the biggest part of sustainable food production, while in high-density Asian cities, like Hong Kong Tokyo and Kuala Lumpur, the focus seems to be on improving the sustainable food production inside the city centers.

In addition, VF has provided new opportunities for architecture and urban designing. Urban designers have attested to the importance of making cities green, healthy and safe. By combining food production and architecture, VF helps to produce buildings capable of multiple functions. This is accompanied by many social and ecological advantages (Thomaier et al., 2015).

\section{REFERENCE}

Abel, C. (2010). The vertical garden city: towards a new urban topology. CTBUH Journal, (2), 20-30. Retrieved September 5, 2010, from http://www.et2050.eu/et2050_library/docs/ tech/land_uses/Vertical_garden.pdf

Afrin, S. (2009). Green Skyscraper: Integration of Plants into Skyscrapers. (Master's Thesis).Kungliga Tekniska högskolan (KTH), Stockholm. Retrieved January 15, 2009 from www.infra.kth.se/sb/sp

Ahlström, L., \& Zahra, M. (2011). Integrating a Greenhouse in an Urban Area. (Unpublished Master's Thesis).Chalmers University of Technology,Göteborg, Sweden.

Al-Chalabi, M. (2015). Vertical farming: Skyscraper sustainability? Sustainable Cities and 
Society, 18, 74-77. Retrieved February 10, 2015 from http://doi.org/10.1016/j.scs. 2015.06.003

Albajes, R., Cantero-Martínez, C., Capell, T., Christou, P., Farre, A., Galceran, J., Voltas, J. (2013). Building bridges: an integrated strategy for sustainable food production throughout the value chain. Molecular Breeding, 32(4), 743-770. Retrieved June 15, 2013 from http://doi.org/10.1007/ s11032-013-9915-z

Ankri, D. S. (2010). Urban Kibbutz: Integrating Vertical Farming and Collective Living in Jerusalem, Israel. (Master's Thesis).Available from ProQuest Dissertations and Theses database. (UMI No.1482437). Retrieved July 2, 2010 from http://search.proquest.com/ docview/762216845?accountid=10906\%5Cnhttp://zsfx.lib.iastate.edu:3410/sfxlcl41?url_ve r=Z39.88-2004\&rft_val_fmt=info:ofi/fmt:kev:mtx:dissertation\&genre=dissertations+\%26+ theses\&sid=ProQ:ProQuest+Dissertations+\%26+Theses+Global\&at

Banerjee, C., \& Adenaeuer, L. (2014). Up, Up and Away! The Economics of Vertical Farming. Journal of Agricultural Studies, 2(1), 40. Retrieved January 15, 2014 from http://doi.org/10.5296/jas.v2i1.4526

Besthorn, F. H. (2013). Vertical Farming: Social Work and Sustainable Urban Agriculture in an Age of Global Food Crises. Australian Social Work, 66(2), 187-203. Retrieved December 5, 2013 from http://doi.org/10.1080/0312407X.2012.716448

Bohn, K., \& Viljoen, A. (2011). The edible city: envisioning the Continuous Productive Urban Landscape (CPUL). Field Journal, 4(1), 149-161. Retrieved June 12, 2011 from http://www.field-journal.org/index.php?page=issue-4

Brundtland, G. H. (1985). World commission on environment and development. Environmental Policy and Law, 14(1), 26-30.

Cicekli, M., \& Barlas, N. T. (2014). Transformation of today greenhouses into high technology vertical farming systems for metropolitan regions. Journal of Environmental Protection and Ecology, 15(4), 1779-1785.

Despommier, D. (2009). The rise of vertical farms. Scientific American, 301(5), 80-87.

Despommier, D. (2010). The vertical farm: feeding the world in the 21 st century. Macmillan.

Despommier, D. (2011). The vertical farm: controlled environment agriculture carried out in tall buildings would create greater food safety and security for large urban populations. Journal Für Verbraucherschutz Und Lebensmittelsicherheit, 6(2), 233-236. Retrieved March 15, 2011 from http://doi.org/10.1007/s00003-010-0654-3

Despommier, D. (2013). Farming up the city: The rise of urban vertical farms. Trends in Biotechnology, 31(7), 388-389. Retrieved December 7, 2013 from http://doi.org/ 10.1016/j.tibtech.2013.03.008

Despommier, D. (2014). Encyclopedia of Food and Agricultural Ethics (Vertical Farms in Horticulture). (P. B. Thompson \& D. M. Kaplan, Eds.) Encyclopedia of Food and Agricultural Ethics. Dordrecht: Springer Netherlands. Retrieved July 15, 2014 from http://doi.org/10.1007/ 978-94-007-0929-4

Dubbeling, M. (2011). Integrating urban agriculture in the urban landscape. Urban Agriculture Magazine, (25), 43-46. Retrieved September 4, 2011 from www.ruaf.org

Eigenbrod, C., \& Gruda, N. (2015). Urban vegetable for food security in cities. A review. Agronomy for Sustainable Development, 35(2), 483-498. Retrieved January 15, 2015 from http://doi.org/10.1007/s13593-014-0273-y

Ellingsen, E., \& Despommier, D. (2008). The Vertical Farm - The origin of a 21 st century Architectural Typology. CTBUH Journal, (3), 26-34. Retrieved June 10, 2008 from 
Kalantari F., Mohd Tahir O., Akbari Joni R., Fatemi E.: Opportunities and Challenges in Sustainability of Vertical Farming: A Review

http://global.ctbuh.org/resources/papers/download/449-the-vertical-farm-the-origin-of-a-21 st-century-architectural-typology.pdf

Ellis, J. (2012). Agricultural Transparency: Reconnecting Urban Centres With Food Production. (Unpublished Master's Thesis).Dalhousie University,Halifax, Nova Scotia.

Germer, J., Sauerborn, J., Asch, F., de Boer, J., Schreiber, J., Weber, G., \& Müller, J. (2011). Skyfarming an ecological innovation to enhance global food security. Journal Für Verbraucherschutz. Und Lebensmittelsicherheit, 6(2), 237-251. Retrieved April 18, 2011 from http://doi.org/10.1007/ s00003-011-0691-6

Glaser, J. A. (2012). Green chemistry with nanocatalysts. Clean Technologies and Environmental Policy, 14(4), 513-520. Retrieved April 15, 2012 from http://doi.org/ 10.1007/s10098-012-0507-0

Graff, G. (2009). A greener revolution: An argument for vertical farming. Plan Canada, 49(2), 49-51.

Hui, S. C. M. (2011). Green roof urban farming for buildings in high-density urban cities. In World Green Roof Conference (pp. 1-9). Retrieved December 2, 2011 from http://www.mech.hku.hk/bse/greenroof/110318_WGRC2011_Hainan_SamHui_fullpaper.p df

Islam, R., \& Siwar, C. (2012). The analysis of urban agriculture development in Malaysia. Advances in Environmental Biology, 6(3), 1068-1078.

Kalantari, F., Mohd Tahir, O., Golkar, N., \& Ismail, N. A. (2015). Socio-Cultural Development of Tajan Riverfront, Sari, Iran. Advances in Environmental Biology, 9(27), 386-392.

Kalantari, F., Mohd Tahir, O., Golkar, N., \& Kalantari, S. (2015). Restoration of Tajan River through ecological design approach. ALAM CIPTA, International Journal on Sustainable Tropical Design Research \& Practice, 8(spec. 1), 52-59. Retrieved April 2, 2015 from http://psasir.upm.edu.my/42296/

Kaplan, R. (1993). The role of nature in the Context of the workplace. Landscape and Urban Planning, 26(1), 193-201. Retrieved September 16, 1993 from http://search.ebscohost. com/login.aspx?direct=true \&db=psyh\&AN=1985-16132-001\&site=eds-live \&scope=site

Kim, H.-G., Park, D.-H., Chowdhury, O. R., Shin, C.-S., Cho, Y.-Y., \& Park, J.-W. (2014). Location-Based Intelligent Robot Management Service Model Using RGPSi with AoA for Vertical Farm. In Lecture Notes in Electrical Engineering (Vol. 279, pp. 309-314). Retrieved January 15, 2014 from http://doi.org/10.1007/978-3-642-41674-3_44

La Rosa, D., Barbarossa, L., Privitera, R., \& Martinico, F. (2014). Agriculture and the city: A method for sustainable planning of new forms of agriculture in urban contexts. Land Use Policy, 41, 290-303. Retrieved March 15, 2014 from http://doi.org/10.1016/j.landusepol. 2014.06.014

Lam, S. O. (2007). Urban Agriculture in Kingston: Present and Future Potential for Re-Localization and Sustainability. (Unpublished Master's Thesis).Queen's University,Ontario,Canada.

Liu, X. (2014). Design of a Modified Shipping Container as Modular Unit for the Minimally Structured \& Modular Vertical Farm ( MSM-VF ). (Master's Thesis).Available from ProQuest Dissertations and Theses database. (UMI No.1573000).

Miller, A. (2011). Scaling Up or Selling Out? A Critical Appraisal of Current Development in Vertical Farming. (Unpublished Master's Thesis).Carleton University,ottawa, 
ontario,Canada.

Nochian, A., Mohd Tahir, O., Maulan, S., \& Rakhshandehroo, M. (2015). A comprehensive public open space categorization using classification system for sustainable development of public open spaces. ALAM CIPTA, International Journal on Sustainable Tropical Design Research \& Practice, 8(spec. 1), 29-40.

Perez, V. M. (2014). Study of The Sustainability Issue of Food Production Using Vertical Farm Methods in An Urban Environment Within The State of Indiana. (Master's Thesis).Available from ProQuest Dissertations and Theses database. (UMI No.1565090).

Platt, P. (2007). Vertical Farming: An Interview with Dickson Despommier. Gastronomica, 7(2), 80-87. Retrieved March 15, 2007 from http://doi.org/10.1525/gfc.2007.7.3.80

Safikhani, T., Abdullah, A. M., Ossen, D. R., \& Baharvand, M. (2014). A review of energy characteristic of vertical greenery systems. Renewable and Sustainable Energy Reviews, 40, 450-462. Retrieved August 25, 2014 from http://doi.org/10.1016/j.rser.2014.07.166

Sauerborn, J. (2011). Skyfarming: an alternative to horizontal croplands. Resource: Engineering \& Technology for a Sustainable World, 18(1), 19. Retrieved December 15, 2011 from http://www.highbeam.com/doc/1G1-247226253.html

Säynäjoki, E., Heinonen, J., \& Junnila, S. (2013). Urban Density and Local Sustainability A Case Study in Finland. In 189TH Annual Pacific-RIM Real Estate Society Conference Melbourne Australia (pp. 13-16).

Sivamani, S., Bae, N.-J., Shin, C.-S., Park, J.-W., \& Cho, Y.-Y. (2014). An OWL-Based Ontology Model for Intelligent Service in Vertical Farm. In Lecture Notes in Electrical Engineering (Vol. 279, pp. 327-332). Retrieved January 5, 2014 from http://doi.org/ 10.1007/978-3-642-41674-3_47

Sivamani, S., Bae, N., \& Cho, Y. (2013). A Smart Service Model Based on Ubiquitous Sensor Networks Using Vertical Farm Ontology. International Journal of Distributed Sensor Networks, 9(12), 161495. Retrieved April 20, 2013 from http://doi.org/10.1155/2013/161495

Sivamani, S., Kwak, K., \& Cho, Y. (2014). A Rule Based Event-Driven Control Service for Vertical Farm System. In J. J. Park, I. Stojmenovic, M. Choi, \& F. Xhafa (Eds.), In Future Information Technology (Vol. 276, pp. 915-920). Berlin, Heidelberg: Springer Berlin Heidelberg. Retrieved September 15, 2014 from http://doi.org/10.1007/978-3-642-55038 $-6 \_138$

Specht, K., Siebert, R., Hartmann, I., Freisinger, U. B., Sawicka, M., Werner, A., Dierich, A. (2014). Urban agriculture of the future: an overview of sustainability aspects of food production in and on buildings. Agriculture and Human Values, 31(1), 33-51. Retrieved January 15, 2014 from http://doi.org/10.1007/s10460-013-9448-4

Tan, Z., Lau, K. K.-L., \& Ng, E. (2015). Urban tree design approaches for mitigating daytime urban heat island effects in a high-density urban environment. Energy and Buildings. Retrieved February 8, 2015 from http://doi.org/10.1016/j.enbuild.2015.06.031

Thomaier, S., Specht, K., Henckel, D., Dierich, A., Siebert, R., Freisinger, U. B., \& Sawicka, M. (2015). Farming in and on urban buildings: Present practice and specific novelties of Zero-Acreage Farming (ZFarming). Renewable Agriculture and Food Systems, 30(1), 43-54. Retrieved April 21, 2015 from http://doi.org/10.1017/S1742170514000143

Vogel, G. (2008). Upending the traditional farm. Science, 319(5864), 752-753. Retrieved August 3, 2008 from http://www.sciencemag.org/cgi/doi/10.1126/science.319.5864.753

Voss, P. M. (2013). Vertical Farming: An agricultural revolution on the rise. Halmstad, 1-21. Wagner, C. G. (2010). Vertical Farming: An Idea Whose Time Has Come Back. Futurist, 
Kalantari F., Mohd Tahir O., Akbari Joni R., Fatemi E.: Opportunities and Challenges in Sustainability of Vertical Farming: A Review

44(2), 68-69. Retrieved October 30, 2010 from http://content.ebscohost.com/

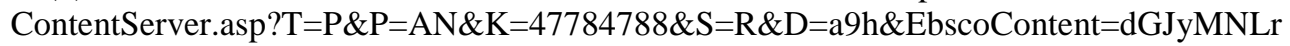
40SeprM4xNvgOLCmr0uep7FSsKu4TLGWxWXS\&ContentCustomer=dGJyMPGvrki3rK 5PuePfgeyx44Dt6fIA\%5Cnhttps://ezproxy.uttyler.edu/login?url=http://search.ebscohost.co $\mathrm{m} / \mathrm{lo}$ 